This PDF is a selection from an out-of-print volume from the National Bureau of Economic Research

Volume Title: Tax Policy and the Economy, Volume 10

Volume Author/Editor: James M. Poterba, editor

Volume Publisher: MIT Press

Volume ISBN: 0-262-16161-3

Volume URL: http://www.nber.org/books/pote96-1

Conference Date: November 7, 1995

Publication Date: January 1996

Chapter Title: Tax Reforms and Labor Supply

Chapter Author: Nada Eissa

Chapter URL: http://www.nber.org/chapters/c10901

Chapter pages in book: (p. 119 - 151) 


\title{
TAX REFORMS AND LABOR SUPPLY
}

\author{
Nada Eissa \\ University of California-Berkeley and NBER
}

The 1980s were a period of substantial changes in the U.S. tax code and income distribution. Even after controlling for demand-side factors that altered the returns to education, researchers have shown that behavioral responses to tax reform remain substantial. This paper reviews the lessons that have emerged from research on the behavioral response to tax reforms, focusing primarily on the labor supply response. The paper also builds on that work by examining whether the dramatic responses in taxable income over the 1980 s are due to an increase in male labor market participation. Microdata from 1976 to 1993 are consistent with only a small male labor supply response after the Tax Reform Act of 1986. This finding is important for the interpretation of previous work and for the design of tax policy.

\section{INTRODUCTION}

The 1980s were a period of substantial changes in the U.S. tax code. Between 1980 and 1989, two tax laws collapsed the federal personal income tax schedule from 14 to 2 (nominal) brackets, ${ }^{1}$ reduced the top

This paper was prepared for the 1995 National Bureau of Economic Research Conference on Tax Policy and the Economy, Washington, D.C., November 7. I thank Doug Elmendorf and Jim Poterba for helpful comments on an earlier draft and Mark Rodini and Jimmy Torrez for research assistance. The Institute of Business and Economic Research at the University of California-Berkeley provided financial support.

1 The phaseout of the personal exemption and the 15 percent bracket created additional 33 percent brackets for upper income taxpayers. 
marginal rate from 70 to 28 percent, and removed an estimated 6 million poor households from the tax rolls. For the typical family with twice the median income, the marginal rate on income was 15 percentage points lower in 1988 than in 1980 . For the family with the median income, the federal marginal rate was 9 percentage points lower (see Bosworth and Burtless, 1992).

The 1980s were also a period of substantial changes in the income distribution. Between 1980 and 1990, the share of income accruing to the top 5 percent of the family income distribution rose from 15.3 to 17.4 percent. The share of income accruing to the top quintile of that income distribution rose from 41.5 to 44.3 percent. Many explanations for the rising share of income at the top of the distribution have been put forward, mostly related to changes in the returns to education that derive from the demand side of the market. Even after controlling for other factors, several researchers (Lindsey, 1987; Feldstein, 1995; Navratil, 1994; Auten and Carroll, 1995) have shown that behavioral responses to tax reform are part of the explanation for the rising share of income at the top of the distribution. ${ }^{2}$

This paper reviews the evidence on the behavioral response to the tax reforms, focusing primarily on the labor supply response. Several studies provide direct evidence on the labor supply response (Bosworth and Burtless, 1992; Eissa, 1995a, b; Eissa and Liebman, 1995). The studies that look at the taxable response, on the other hand, provide suggestive evidence of labor supply responses. Although that evidence shows that growth in wage and salary income is an important component of the taxable income response (Navratil, 1994; Slemrod, 1995), it does not separate the labor supply response from other factors, such as reporting and compensation decisions.

Although the female labor supply did respond to the incentives in the tax reforms, it is unlikely that the increase in income is due to their increasing labor market participation. Overall, the share of women in the work force increased by 3 percentage points between 1980 and 1990, from 42.4 to 45.4 percent, but unless married, these women are not at the upper end of the income distribution, where we observe most of the income responses. Moreover, women married to high-income men do not earn enough to explain the surge in income. Mean earnings of married women in the highest decile of the taxable income distribution were $\$ 5,100$ in 1985 (\$11,638 conditional on working) (Navratil, 1994).

Essentially all research shows that male participation and hours of

2 The findings are derived from the distribution of taxable income, which can differ from the family income distribution. 
work do not respond to changes in after-tax wages (Hausman, 1985; Pencavel, 1986; Triest, 1992). However, two reasons suggest that studying the male labor supply is important: first, the strong income response to the tax reforms in the 1980s raises the question of whether male labor market participation is an important component. Second, the participation decision of men may have become more responsive to taxes because their participation rate is much lower than it was two decades ago (Heckman, 1993). During 1967-1969, the participation rate of men was 92.7 percent, but by $1985-1987$, it had fallen to 86.8 percent (Juhn, 1992).

This paper examines the labor supply response of prime-age men (between the ages of 16 and 48) to the tax reforms of the 1980s. Using microdata from 1976 to 1993 and estimating simple reduced-form labor supply regressions, I find results that are consistent with a small labor supply response to the tax reforms. For men with more than 16 years of schooling, the estimated increase in total hours of work is about 50 hours per year, or 2 percent. The estimates suggest that the income response observed in the tax return data is due more to other factors, such as shifting of income, other dimensions of labor supply (productivity, occupational choice), and compensation decisions.

The current paper is organized as follows. Section 2 describes important features of the U.S. tax reforms from 1980 to 1993 and covers changes in the taxation of earned income resulting from the Economic Recovery Tax Act of 1981 (ERTA), the Tax Reform Act of 1986 (TRA), and the Omnibus Budget Reconciliation Act of 1993 (OBRA93). Section 3 then reviews the evidence on the behavioral responses to taxes. An analysis of the male labor supply follows in Section 4 , which covers the data and the results. Finally, Section 5 concludes the paper.

\section{TAX REFORMS, 1980-1993}

In this section, I summarize features of the tax laws that are relevant for the treatment of earned income. In addition to the three tax laws passed (ERTA, TRA, and OBRA93), changes in the social security system that affected marginal (and average) rates for many taxpayers are discussed.

The first major tax law of the period, the ERTA, was passed in 1981. The ERTA called for an across-the-board reduction in marginal tax rates of 23 percent, to be phased in between 1982 and $1984 .{ }^{3}$ The top tax rate

3 A secondary earner tax deduction, equal to 10 percent of the earnings of the lower earning spouse up to $\$ 30,000$ was introduced. This provision is unlikely to affect the labor supply decisions of the primary earner (typically the husband) in the most basic labor supply model. 


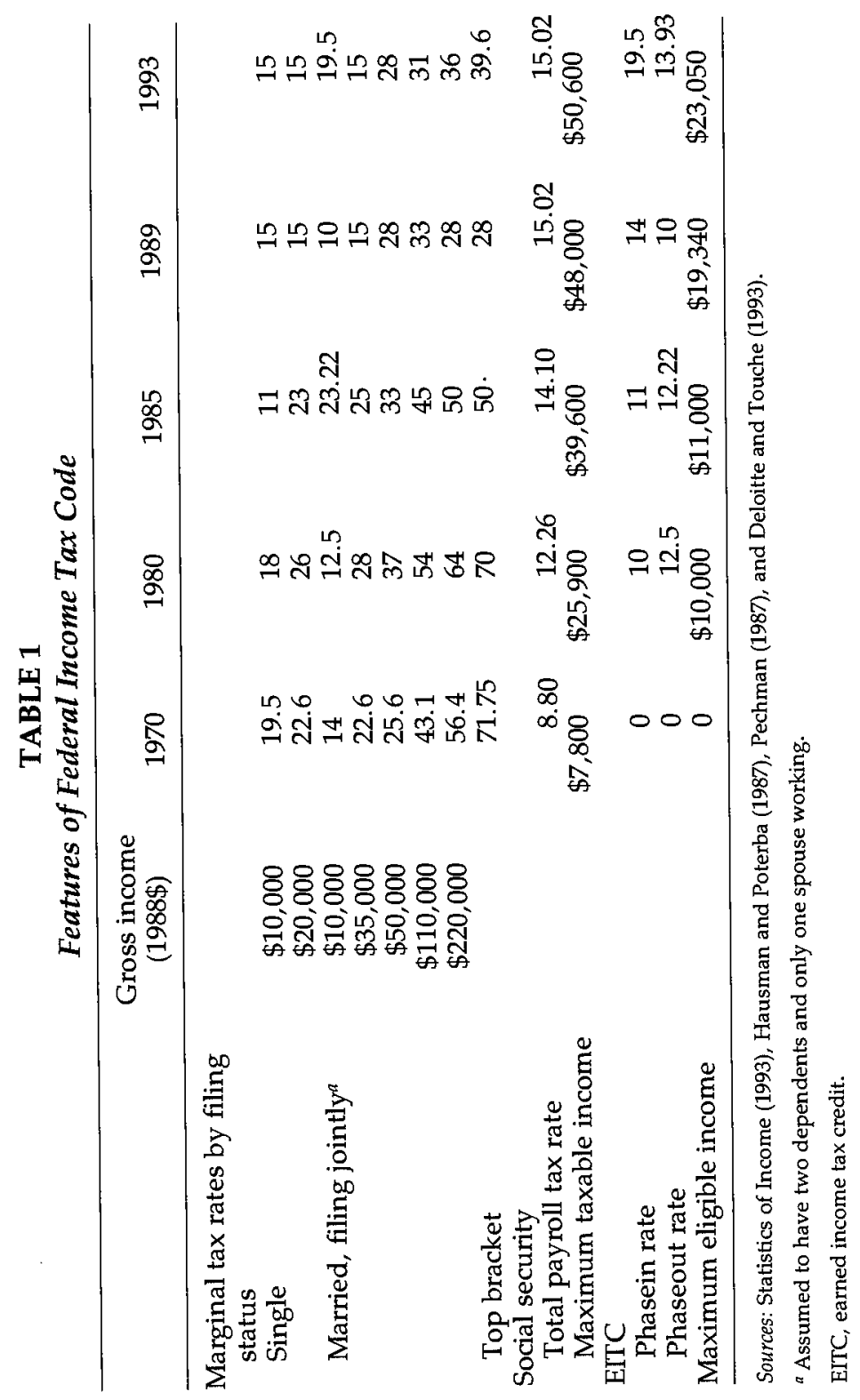


bracket was lowered from 70 to 50 percent, effective in 1982. The ERTA included few provisions to alter the tax base, and so lower marginal rates should have translated into lower average rates for these taxpayers.

Although the ERTA reduced statutory marginal rates within each bracket, this did not translate into lower effective marginal (and average) rates for many taxpayers. For high-income taxpayers, the effective reduction in marginal rates was less than the implied 20 percentage points because the Maximum Tax, passed as part of the Tax Reform Act of 1969, kept marginal rates on earned income well below the 70 percent rate (see Lindsey, 1981). For many low- and middle-income taxpayers, marginal (and average) rates did not fall because of the increase in social security taxes. The payroll tax (on the employer and the employee) was increased by 2.76 percentage points, and the maximum taxable income was increased from $\$ 25,900$ in 1980 to $\$ 39,600$ in 1985 (Table 1). ${ }^{4}$ This offset a full percentage point of the marginal rate reduction for the taxpayer earning $\$ 35,000$ after the ERTA. ${ }^{5}$ Taxpayers with less than $\$ 50,000$ faced the same or higher effective rates after the ERTA as before (Lindsey, 1987).

The TRA represented a shift in the tax code to low marginal rates imposed on a broad tax base. It was designed to be both revenue neutral and distributionally neutral. The tax law had important effects on lowand high-income taxpayers and little or no effect on a large section of the population. Hausman and Poterba (1987) estimate that more than 40 percent of the population would see a change in marginal rates of less than 10 percent, whereas only 11 percent would face marginal tax reductions of at least 10 percentage points. ${ }^{6}$ The tax law collapsed the previous 11 income tax brackets into 2 (nominal) brackets: 15 and 28 percent. The

However, the deduction should generate some substitution in the labor supply of husband and wife if they make a joint decision.

4 The appropriate social security tax is the difference between the present discounted value of benefits and the present discounted value of taxes. Although the difference is small for men (Feldstein and Samwick, 1992), the properly measured tax rate nonetheless increased during the decade.

${ }^{5}$ For some, the increase in the maximum taxable income raised marginal rates by the full 14 percentage points.

6 To reconcile these figures with the data of Bosworth and Burtless cited previously, it is important to recognize that the effects of the TRA on marginal rates for taxpayers near the median of the income distribution are quite heterogenous. The 15 percent bracket in 1989 included taxpayers who had faced marginal rates between 11 and 24 percent in 1980 . The typical family with the median income in the study by Bosworth and Burtless faced a 24 percent rate in 1980 and a 15 percent rate in 1989. Taxpayers with slightly more income faced the 28 percent rate in 1980 and 1989. Hausman and Poterba (1987) present aggregate figures based on the distribution of taxpayers along the tax schedule. 
phaseout of the 15 percent bracket and the personal exemption created a 33 percent tax bracket for higher income individuals.

For high-income individuals, the TRA reduced the top income marginal rate from 50 to 28 percent by 1988 . Statutory marginal rates fell by at least 10 percentage points for those with taxable income over $\$ 65,000$. The income effect of these marginal rate reductions was offset for higher income individuals by the expansion of the tax base. After the TRA, taxpayers could no longer exclude 60 percent of capital gains from adjusted gross income (AGI), deduct certain interest payments, or use passive losses to offset other income. ${ }^{7}$

For poor Americans, the law affected both average and marginal tax rates. It removed an estimated 6 million taxpayers from the tax rolls by increasing the dependent exemption (from $\$ 1,086$ in 1986 to $\$ 1,950$ in 1988 ) and the standard deduction (from $\$ 2,480$ in 1986 to $\$ 4,400$ in 1988 for a taxpayer filing as head of household). In addition, the Earned Income Tax Credit (EITC) was expanded. The EITC is a refundable credit, so taxpayers who owed no taxes could have received a refund of up to $\$ 874$ in $1988 .^{8}$ The expansions in the EITC and other provisions in the TRA of 1986 reduced the tax liability for the average female head of household by $\$ 1,100$ (Eissa and Liebman, 1995).

Although the Omnibus Budget Reconciliation Act of 1990 increased the top rate to 31 percent, by the early 1990 s marginal rates on the highest income Americans were substantially lower than a decade earlier (see Table 1). Partially to redress the perceived inequities in the tax system due to the tax reforms of the 1980s, the OBRA93 included several provisions to increase the progressivity of the tax code. The OBRA93 increased marginal rates for high-income individuals. It created a new tax bracket, 36 percent for taxpayers earning over $\$ 140,000$. Also, a surtax on individuals earning more than $\$ 250,000$ effectively created a 39.6 percent bracket. 9

7 The TRA also increased the corporate income tax, generating additional income and substitution effects for some high-income individuals.

8 The EITC creates a complicated and ambiguous set of labor supply incentives. Standard labor supply theory predicts that the EITC will encourage labor force participation because it is available only to taxpayers with earned income. But theory also predicts that the credit reduces the number of hours worked by most eligible taxpayers already in the labor force. Although the credit initially increases with income, producing offsetting income and substitution effects on hours worked, more than 70 percent of recipients have incomes in regions in which the credit is constant (and therefore produces only a negative income effect on labor supply) or is being phased out (producing negative income and substitution effects).

${ }^{9}$ Additional provisions in the OBRA93 raised the highest marginal rate even further. Taxpayers earning more than $\$ 108,450$ were required to reduce their itemized deductions by 3 percent and thus faced a marginal rate of 41 percent. Also, the law adds another 2.9 
The OBRA93 also expanded the EITC for low-income individuals. The expansions of the EITC are such that by 1996, it will surpass Aid to Families with Dependent Children (AFDC) as the largest federal program to alleviate poverty. The credit is scheduled to be phased in at a 40 percent rate up to a maximum of $\$ 3,370$ for a family with two or more children and at a 34 percent rate for a family with one child up to a maximum of $\$ 2,040$.

These tax reforms clearly generated both income and substitution effects. To consider their effects, we refer to the basic model generally used to analyze labor supply and taxes. The model hypothesizes that the individual maximizes utility to determine consumption (of a composite good) and hours of work. A tax increase makes the individual poorer and reduces his consumption of leisure (increases work). This is the income effect. A tax also reduces the after-tax wage and makes the individual work less. This is the substitution effect. Since these effects work in opposite directions, the net effect of tax reform on labor supply is usually ambiguous. Under some circumstances, the direction of the labor supply effect of a tax reform can be certain. A tax reform that reduces marginal rates but leaves average rates constant has an unambiguous positive effect on hours of work.

\section{WHAT ACTUALLY HAPPENED: BEHAVIORAL RESPONSES TO TAX REFORMS}

The tax reforms of the 1980s gave economists an unprecedented opportunity to study individual behavioral responses to taxes. ${ }^{10}$ To study the

percent (on the employer and the employee) to the marginal rate for workers with wages and salary over $\$ 135,000$ by eliminating the cap on the hospital insurance portion of social security.

10 To place the following discussion in context, it is useful to consider the labor supply literature in the early 1980s and its implications for the effects of the tax reforms on labor supply. Since the labor supply literature is large and has been reviewed extensively elsewhere (see Hausman, 1985; Pencavel, 1986; Heckman and Killingsworth, 1986), the focus here is on research based on Hausman (1981). For a critique of the Hausman study, see MaCurdy, Green, and Paarsch (1990). Hausman estimated preference parameters by solving an optimizing model in which the nonlinear and nonconvex budget constraints facing the taxpayers are carefully modeled. Using maximum likelihood methods and crosssectional data from the 1975 Panel Study of Income Dynamics (PSID), Hausman estimated total hour elasticities for married women and female heads of households similar to those in the literature at the time. For men, however, his estimates differed markedly. Although Hausman estimated an uncompensated elasticity of near zero for men, he found a large income effect and by definition a large substitution effect of taxes. The important implication of these estimates is that although the tax system does not affect hours worked, it affects economic welfare. 
behavioral response to the tax reforms, researchers have used repeated cross sectional data (Lindsey, 1987; Feenberg and Poterba, 1993; Eissa, 1995a), aggregate time series data (Bosworth and Burtless, 1992; Slemrod 1995), and panel data (Feldstein, 1995; Navratil, 1994; Auten and Carroll, 1995). The story that emerges from this work is that behavioral responses to taxes are significant, especially for high-income individuals. In this section, I review the evidence on the response in labor supply and more generally in taxable income. A review of the taxable income response is important because it remains unexplained and raises the question of whether male labor supply is part of the response.

\subsection{Total Labor Supply}

Bosworth and Burtless (1992) were the first to study the labor supply response to the tax reforms of the 1980s directly. They used aggregate data from 1967 to 1989, which they generated from the Current Population Survey (CPS) to estimate time-series hours of work regressions. Their specification allowed two linear trends, one from 1967 to 1989 and another starting in 1981, and an adjustment for business cycle effects. Their regression estimates suggested that men worked 6 percent more hours and women 5.4 percent more hours in 1989 than in 1981.

To exploit the heterogeneous effect of the tax reforms on individuals, Bosworth and Burtless (1992) analyzed responses for individuals at different quintiles of the income distribution. They found that individuals in the bottom quintile increased their labor supply the most. They estimated a 31 and 16.7 percent increase in total hours worked by men and women, respectively, in the bottom quintile, but only a 3.2 and 11.8 percent increase by men and women in the top quintile. As they note, this pattern is not consistent with a pure labor supply story. Marginal and average rates remained largely unchanged for the bottom quintile, whereas they fell for the top quintile. Because the pattern of responses does not show that highest income individuals respond most, they concluded that their results only weakly support the prediction of a labor supply response.

However, the anomaly of large responses by men and women in the

Hausman (1981) used his estimates to simulate the labor supply effects of 10 and 30 percent reductions in marginal rates. He estimated that a 10 percent reduction in marginal rates would increase labor supply by 1.1 percent for men and 4.1 percent for women, whereas a 30 percent reduction would increase labor supply by 2.7 percent for men and 9.4 percent for women. The expectation in the early 1980 s was that labor supply would increase substantially after the ERTA, which bracketed the Hausman simulations. Later in the decade, Hausman and Poterba (1987) also used the Hausman estimates to predict the effects of the TRA of 1986 . They concluded that the TRA of 1986 would have only modest effects on aggregate labor supply because it had only modest effects on marginal rates. 
bottom quintile may be partially explained by the business cycle. In 1981, the national unemployment rate was 7.6 percent. By 1989 , it had fallen to 5.3 percent, the lowest rate since 1973 . The bottom quintile of the family income distribution in 1981 will include a disproportionate number of individuals who are unemployed because of the recession. Although Bosworth and Burtless (1992) adjust for business cycle effects in their regressions, their procedure almost builds in a response after 1981. This built-in increase in labor supply by men in the bottom quintile results from depressing their total hours worked in 1981 by allocating to that group men who are strongly affected by the recession.

Another anomaly from the perspective of a tax response is that hours worked by older groups (between ages 45 and 64) increased at a faster rate after 1981 than hours worked by younger groups. However, labor market participation by older men may be responding to different factors, such as social security and private pensions. The large increase in the growth of social security benefits throughout the late 1960s and 1970s and the subsequent decline in the 1980s may explain part of the trend in the labor market participation of older men.

\subsection{Female Labor Supply}

In this section I review studies that focused on the female labor supply response to the tax reforms (Eissa, 1995a,b; Eissa and Liebman, 1995). Eissa $(1995 a, b)$ analyzed the effect of the TRA and ERTA on the labor supply of married women, and Eissa and Liebman (1995) analyzed the effect of the EITC and other provisions in the TRA on the labor supply of female heads of households.

These studies differ from Bosworth and Burtless (1992) in the data and methodology used. Although all the studies used the March CPS, Bosworth and Burtless (1992) used data from 1967 to 1989, whereas Eissa (1995a,b) and Eissa and Liebman (1995) used data immediately surrounding the actual tax acts. In addition, Bosworth and Burtless (1992) aggregated the data by demographic group, and so had a single annual observation for each group. Eissa (1995a,b) and Eissa and Liebman (1995), in contrast, used individual data. This strategy reflected the source of variation used to estimate the effect of the tax laws. By aggregating the data, Bosworth and Burtless (1992) relied on time to identify the effects of the tax laws. In their study, the change in the time trend starting in 1981 signaled the response to the tax reforms. The Eissa $(1995 \mathrm{a}, \mathrm{b})$ and Eissa and Liebman (1995) studies, discussed in more detail in this section, relied on variation in marginal rates over time and between groups to identify the effect of the law.

The idea of these reports is that tax reforms offer time variation in 
marginal and average rates that is arguably more exogenous than is available in the cross section. Generally, cross-sectional labor supply equations are hard to estimate for reasons that relate to endogenous and missing wages, taxes, and nonlinear budget sets. The first problem is that taxes and labor supply are endogenously determined. A second problem is that cross-sectional differences in after-tax wages result from differences in education, family structure and size, and other factors that also affect labor supply decisions. A third problem encountered in the empirical analysis of taxation and labor supply is that nonlinear budget sets, owing to a progressive tax schedule, complicate the estimation procedure considerably.

To avoid these complications, these studies focused on groups that were strongly affected by the tax laws. To estimate the effect of the law, they compared the change in labor supply of women whose incentives were greatly affected with those whose incentives were little affected. For example, the TRA reduced marginal rates for women whose husbands were at the top of the income distribution but less so for those whose husbands were lower in the income distribution. The EITC, on the other hand, affected single women with qualifying children and did not affect single women without children. ${ }^{11}$ The difference in the change in hours worked by these two groups is an estimate of the effect of the law.

The assumption that identifies the effect of the policy is that allocation to the treatment (affected) group is exogenous. If there were no assortative mating (people did not marry those who are like them), or if having a child were an exogenous event, this assumption would generate treatment and control groups that have the same distribution of preferences and characteristics. However, it is unlikely that any policy change would differentially affect otherwise identical groups. Women who marry upper income men are observationally different from women who marry lower income men. To overcome this problem, we control for relevant characteristics. Once observable characteristics are controlled for, the assumption is weakened substantially. To identify the response, we require that the distribution of unobservables remains constant over time.

To control for differences in the observable characteristics of the respective groups, Eissa (1995a,b) and Eissa and Liebman (1995) estimate equations of the following form:

11 A qualifying child is a child, grandchild, stepchild, or foster child of the taxpayer; is under the age of 19 (under 24 if a full-time student) or permanently disabled; and has lived with the taxpayer for more than one half of the tax year. 


$$
l_{i t}=f\left(\alpha_{0}+\alpha_{1} Q_{i t}+\beta_{0} I_{j}+\beta_{1} I_{t}+\beta_{2} I_{j t}\right),
$$

where $I_{j}$ is a dummy variable for the treatment group (and is zero for the control group); $I_{i}$ is a dummy variable for time ( $t=1$ after the tax acts); $I_{j t}$ is the product of the time and group dummy variables; $Q$ includes observable characteristics of the individual; $l_{i t}$ is the measure of labor supply (participation and hours worked); and $f$ is the normal density in the participation equation.

This "difference-in-difference" approach requires that there are no contemporaneous changes in policy or other factors that differentially affect the two groups. Where possible, one can account for such occurrences by changing the specification of $Q$. For example, high-income women have more education than low-income women at a time when returns to education were increasing. Such differences can bias the results because they conflate the effects of increased demand with responses to tax reductions. If $Q$ includes a variable that interacts education with time, the bias is reduced.

Using imputed marginal tax rates, the elasticity of labor supply is calculated as follows:

$$
\eta=\frac{\beta_{2}}{\Delta(1-\tau)^{T}-\Delta(1-\tau)^{C}}
$$

where $\beta_{2}$ is the difference in labor supply changes (see equation [1]); $\tau$ is the marginal rate; $\Delta$ is the percent change; $T$ is the treatment group; and $C$ is the control group.

3.2.1 Married Women Using data from the 1984-1986 and 1990-1992 March CPS, Eissa (1995a) identified the impact of tax reform by comparing the change in labor supplied by higher income women to the change in labor supplied by women with less income. Higher income women were those whose other household income (husband's earned income and family unearned income) placed them at or above the 99th percentile of the CPS income distribution; women with less income were between the 75th and 80th and the 90th and 95th percentiles of the same income distribution.

Table 2 presents the figures for the increase in labor force participation and in total labor supply under different assumptions. These figures are based on predictions from participation and hours-worked regressions, specified as equation (1). The top panel shows the relative increase in the labor force participation rate of high-income married women; the bottom 


\section{TABLE 2}

Effects of TRA of 1986 on Labor Supply of High-Income Married Women and Their Elasticity Estimates

\begin{tabular}{lcccc}
\hline Control group & $\begin{array}{c}\text { Raw data } \\
(\%)\end{array}$ & $\begin{array}{c}\text { Demographic } \\
\text { controls (\%) }\end{array}$ & $\begin{array}{c}\text { Adding education } \\
\text { interaction (\%) }\end{array}$ & $\begin{array}{c}\text { Elasticity } \\
\text { estimate }\end{array}$ \\
\hline $\begin{array}{l}\text { Participation response } \\
\quad\end{array}$ & 34.5 & & & \\
$\quad$ No control group & 12.3 & 8.4 & 4.3 & $0.2-0.4$ \\
$\quad$ 75th percentile & 13.0 & 10.9 & 11.4 & 0.6 \\
$\quad$ 90th percentile & & & & \\
Total labor supply & 19.5 & 18.4 & 12.3 & $0.6-1.0$ \\
$\quad$ No control group & 22.8 & 16.9 & 14.6 & $0.9-1.0$ \\
$\quad$ 75th percentile & 19.8 & & & \\
90th percentile & &
\end{tabular}

Data are March Current Population Survey 1984-1986 and 1990-1992; see Eissa (1995a) for details.

panel presents the corresponding figures for the increase in total hours of work per year. Although several estimates of the impact of the TRA are plausible, all point to the general conclusion that the labor supply of married women increased after the reduction in marginal tax rates. The relative participation increase of 19.5 percent ( 9 percentage points) and the relative hours increase of 34.5 percent ( 206 hours per year) are contaminated by several factors, including a trend component and other contemporaneous demand shocks. Using different control groups reduces these estimates dramatically. Controlling for observable characteristics reduces the estimated participation response further to 8.4 percent using the first control group and 10.9 percent using the second control group. The corresponding response in total labor supply is in the range of 16.9 to 18.4 percent. These estimates are purged of the trend component and any other factors that are common for women whose husbands have less income but not of factors that differ between higher and lower income women, such as changes in the returns to education.

Because women in the 99th percentile of the income distribution are more educated on average than other women, part of their response may be due to higher gross wages rather than to lower taxes. Allowing different responses by more educated women reduces by one half the labor supply effect for the 75th percentile group: all of this effect is operating through the participation decision. There is no analogous effect for the 90th percentile group; this result is not surprising since the difference in average education levels between this control group and the treatment group is only half a year.

The estimates in Eissa (1995a) suggest a total labor supply elasticity 
between 0.6 and 1 (including both participation and hours of work). Approximately half this response is due to participation. Although the total elasticity estimate is not very different from previous estimates in the literature, its composition is different. Mroz (1987) and Triest (1990) found that hours of work for working women are not affected by the after-tax wage and suggest that the participation decision is responsive to the wage.

In a similar analysis of the ERTA, Eissa (1995b) found a similar overall elasticity but that most of the response to tax reductions results from additional participation. Several differences between the ERTA and TRA can help explain these findings, but the basic explanation is that the 1981 "experiment" is not as clean as the 1986 one. Changes in the income distribution and growth in wage inequality were particularly dramatic in the early 1980s. Moreover, the marginal tax reductions were much larger in 1986 than in 1981. The different results point out a potential problem with the "difference-in-difference" approach, which is that it estimates only the net effect of the policy. I return to this issue in Section 5.

3.2.2 Female Heads of Households Eissa and Liebman (1995) focused on the effects of the TRA and EITC on single women with children. Female heads of households are an important group because they are the largest group of taxpayers eligible for the EITC, making up approximately 48 percent of the EITC-eligible population (Eissa and Liebman, 1993). They identified the impact of the EITC by comparing the change in labor supplied by women with children to the change in labor supplied by women with no children.

Table 3 presents the estimated labor supply response of female heads of households. Eissa and Liebman (1995) found that after the TRA, the labor force participation of single women with children increased by 1.9 to 2.8 percentage points relative to single women without children (from a base of 73.0 percent). They argue that this 2.6 to 3.8 percent increase in participation can be thought of as a response to a $\$ 1,100$ increase in aftertax income.

Three pieces of evidence suggest that the estimated effect was due to the EITC and not to other parts of the TRA or other government policies. First, in the period that they studied, the amount of EITC a taxpayer received depended only on having a child, and they found that the increase in participation is mostly a response to the return to the first child in the tax unit. The effect of the EITC falls from 3.8 to 3.3 percent once they allow a different response for families with at least two children. Second, the timing of the post- 1987 participation increase is consistent with the result being due to the increase in the EITC. Most EITC 


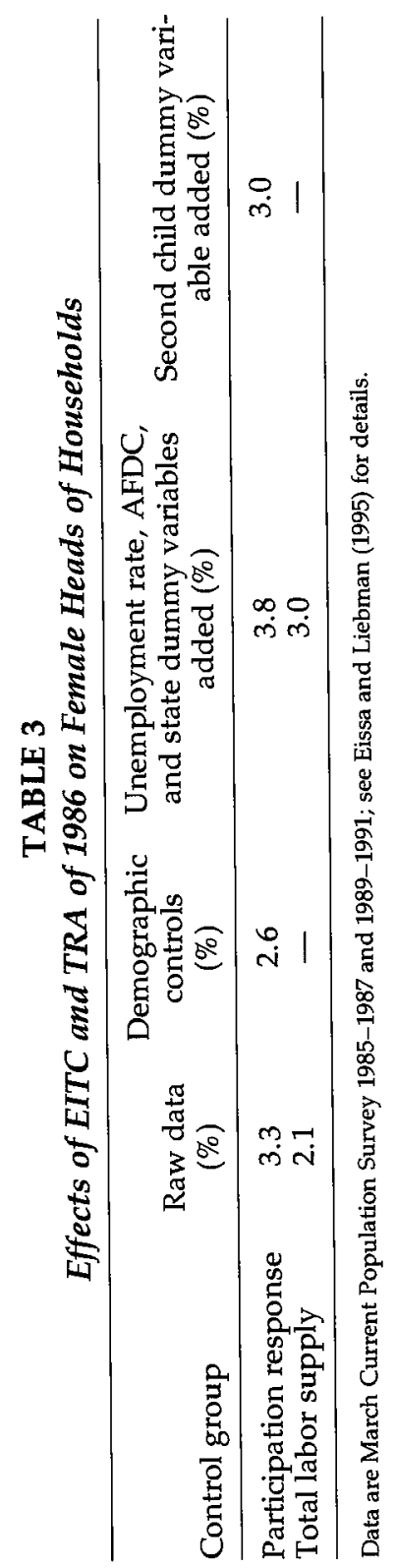


recipients would have first become aware of the increase around April of 1988 when they received their 1987 tax refund. If it takes some time to adjust to new incentives, only a limited response should occur in 1988, with a full response in 1989. Eissa and Liebman (1995) found that by 1988 , single women with children had increased their relative labor supply by only 1.1 percent, but that in 1989 and 1990, the impact reached 4 percent. Third, Eissa and Liebman (1995) found that the EITC had its largest effect among people most likely to be eligible for the credit. The predicted participation response was approximately 13 percent for women with less than 12 years of schooling and only 0.4 percent for women with more than 12 years of schooling.

Eissa and Liebman (1995) also found no evidence that the EITC expansion had any effect on the hours of work of single women with children who were already in the labor force; the estimates for the total-hours response are similar to the participation responses (Table 3).

\subsection{Taxable Income}

Other than Bosworth and Burtless (1992), no studies have directly analyzed the male labor supply response to the tax reforms. In this section, I review the evidence on the taxable income response and argue that the large observed responses beg for a direct examination of the male labor supply over the 1980 s.

In a series of papers, Lindsey $(1987,1988)$ examined the income response to the ERTA. He used tax return data from 1979 and the NBER TAXSIM model to impute an income distribution for 1982-1984, and compared that with the actual income distributions for those years. Comparison of two income distributions showed that high-income taxpayers had substantially more income after 1981 in the actual than in the predicted income distribution, whereas low-income taxpayers had less income.

Imputed marginal tax rates showed that the change in the income distribution was consistent with the incentives of the ERTA. Only highincome taxpayers saw a reduction in their marginal rates after the ERTA. Inflation and expansions in the social security payroll offset most of the marginal rate reductions for middle- and low-income individuals. Using elasticities from the literature, Lindsey calculated that at least 40 percent of the response was from increased hours of work, which he estimates at 2.5 percent between 1981 and 1985. The rest is change in the form of compensation (more money wages and fewer untaxed fringe benefits).

Using panel tax return data, Navratil (1994) estimated a taxable response that is substantial but considerably smaller than Lindsey's. He also found that wage income is an important component of that re- 
sponse and concludes that "wage and salary growth may be more the result of supply-side factors than is generally suspected."12

Tax return panel data were also used by Feldstein (1995) and Auten and Carroll (1995) to study the taxable income response to the TRA. Feldstein grouped taxpayers by their 1985 marginal tax rate and compared their reported taxable income in 1985 with that in 1988 . He estimated a substantial increase in taxable income for upper income taxpayers. Auten and Carroll extended the Feldstein study to account for nontax changes in the economy using data that had a large sample of high-income returns. In addition their data included the occupation of the taxpayer, which they used to control for changes in returns to education and other labor demand factors. They found that half their taxable income response was due to demand factors but still concluded that behavioral responses to the TRA are substantial.

Although the evidence that taxable income responded quite dramatically to the tax reforms is clear, the components of that response are less clear. If we care about the broader dimensions of labor supply (occupational choice, human capital), then the taxable income response is a better measure than hours worked. However, since taxable income includes AGI (wage and salary income, self-employment income, interest, dividends), deductions, and exemptions, it is critical for tax policy that we understand the components of the taxable income response (see Slemrod, 1995).

The evidence that exists shows that both AGI and deductions explain the increase in taxable income at higher incomes (Auten and Carroll, 1995). In addition, the largest source of increase in personal income for the richest individuals between 1984 and 1990 was wages and salaries (45 percent), followed by $S$ corporation income ( 16.5 percent) and partnerships (Slemrod, 1995). ${ }^{13}$

The key question here is to what extent can the widening wage distri-

12 The difference between the results of Navratil $(1994)$ and Lindsey $(1987,1988)$ relates to the data used: repeated cross-sectional versus panel data. There are two components to the argument. First, repeated cross-sectional data require that individuals at successive fractiles of the income distribution are essentially the same in 1979 as they are in later years. However, at least 34 percent, and as much as 77 percent, of 1980 taxpayers are in different deciles of the taxable income distribution by 1983. Second, repeated cross-sectional data require that individuals be grouped by a variable other than actual marginal tax rates, thus averaging away much of the variation in tax changes within a group. Use of panel data overcomes these problems. These arguments are also relevant for the research on labor supply.

13 The TRA reduced the top marginal income tax rate below that of the corporate tax rate and made $S$ corporations, which were subject to the individual income tax, more attractive than $\mathrm{C}$ corporations, which are subject to the corporate income tax. 
bution be explained by changes in labor supply. Although the results in Eissa $(1995 a, b)$ suggest a substantial labor supply response by upper income women, they do not explain the widening income distribution for two reasons. First, even though their labor supply response was substantial, there are too few high-income women. Second, women married to men at the top of the income distribution are only weakly attached to the labor force and earn little income, on average. Mean earnings of married women in the highest decile of the other taxable income distribution were $\$ 5,100$ in 1985 ( $\$ 11,638$ conditional on working) (Navratil, 1994).

Although a voluminous body of work has found that male hours of work and participation are not responsive to economic variables (see Pencavel, 1986), the significant changes in income after the reforms beg the question of whether labor supply (participation and hours worked) responded to tax reforms. Studying male labor supply is therefore important not only for a further understanding of the source of the income response, but for another reason as well. Labor force participation of prime-age men (between the ages of 16 and 48) has declined from 92.7 percent in 1967-1969 to 86.8 percent in 1985-1987. This declining male participation opens the possibility that their participation decision may have become more sensitive to taxation (Heckman, 1993).

\section{NEW EVIDENCE ON BEHAVIORAL RESPONSES TO TAX REFORM}

In this section, I present evidence on the male labor supply behavior over the past two decades. The goal of this exercise is to examine whether the evidence is consistent with a labor supply response to the tax reforms. The examination of the male labor supply response to the tax reforms is more complicated than that of the female labor supply response. Unlike married women, whose tax treatment is based on a husband's and other household income, and female heads of households, whose tax treatment is based on the presence of a child, the tax treatment of men cannot be so easily determined. To exploit the difference in tax changes for men at different points along the income distribution, education is used as a measure of permanent income and groups men by the number of years of schooling completed. I define four groups: less than 12,12,13-16, and more than 16 years of schooling. With this grouping, we can see whether labor supply patterns differed for groups whose incentives were changed in different ways by the ERTA and the TRA. We should expect an increase in labor supplied by 
men with more than 16 years of education to both the ERTA and TRA, but an increase in labor supplied by men with less than 12 years of schooling only after the TRA. If both of these groups have similar labor supply patterns over both periods, then what we estimate is not a response to tax reform.

Two troubling aspects of grouping by education should be noted at the outset. First, although clearly positively correlated with wages, these education classes explain at most 9 percent of the individual variation in wages. There remains significant variation in wages within each group. ${ }^{14}$ Second, returns to education have changed over the same period, making it difficult to isolate the effect of the tax changes. I next discuss the identification of the tax response with the results.

\subsection{Data and Sample}

I use microdata from the 1977-1994 March CPS. ${ }^{15}$ The CPS is a nationally representative data base of approximately 57,000 households. ${ }^{16}$ The March data include retrospective income and labor market activity information, so that the data are actually for 1976-1993.

The sample includes heads of tax-filing units ${ }^{17}$ between 24 and 55 years old, not ill or disabled or in school or retired. It also excludes men who report negative earned income (wage and salary, farm, and selfemployment income) and who report positive earned income but no hours of work for the year. The sample size for all years is 559,592.

Table 4 presents summary statistics for the sample. It also disaggregates the samples by educational attainment. The average man is white, 37 years old, likely to be married, and has completed 1 year of college education. He earns \$26,390 (in 1993 dollars). With 96.7 percent probability, he works at least 1 hour during the year, and he works an average of 2,034 hours, 47 weeks per year. The second to fifth columns in Table 4 separate the sample by years of schooling completed (less than $12,12,13-16$, and more than 16). Again, the idea of separating men by schooling is to isolate groups that are affected differentially by the tax laws. The average man with less than a high school education completes

14 An alternative strategy might be to predict wage income for each individual and use the predicted income to group individuals. This strategy is problematic because of the extended time period considered and the top coding of income in the CPS.

15 Before 1977, the CPS reported weeks worked in brackets and provided hours per week only for the reference period (rather than for the previous year). To avoid imputing the variables of interest, I exclude those years.

16 This number varies over time.

17 Members of related and unrelated subfamilies residing with the primary family are assumed to file their own tax returns and are allocated to separate filing units. 


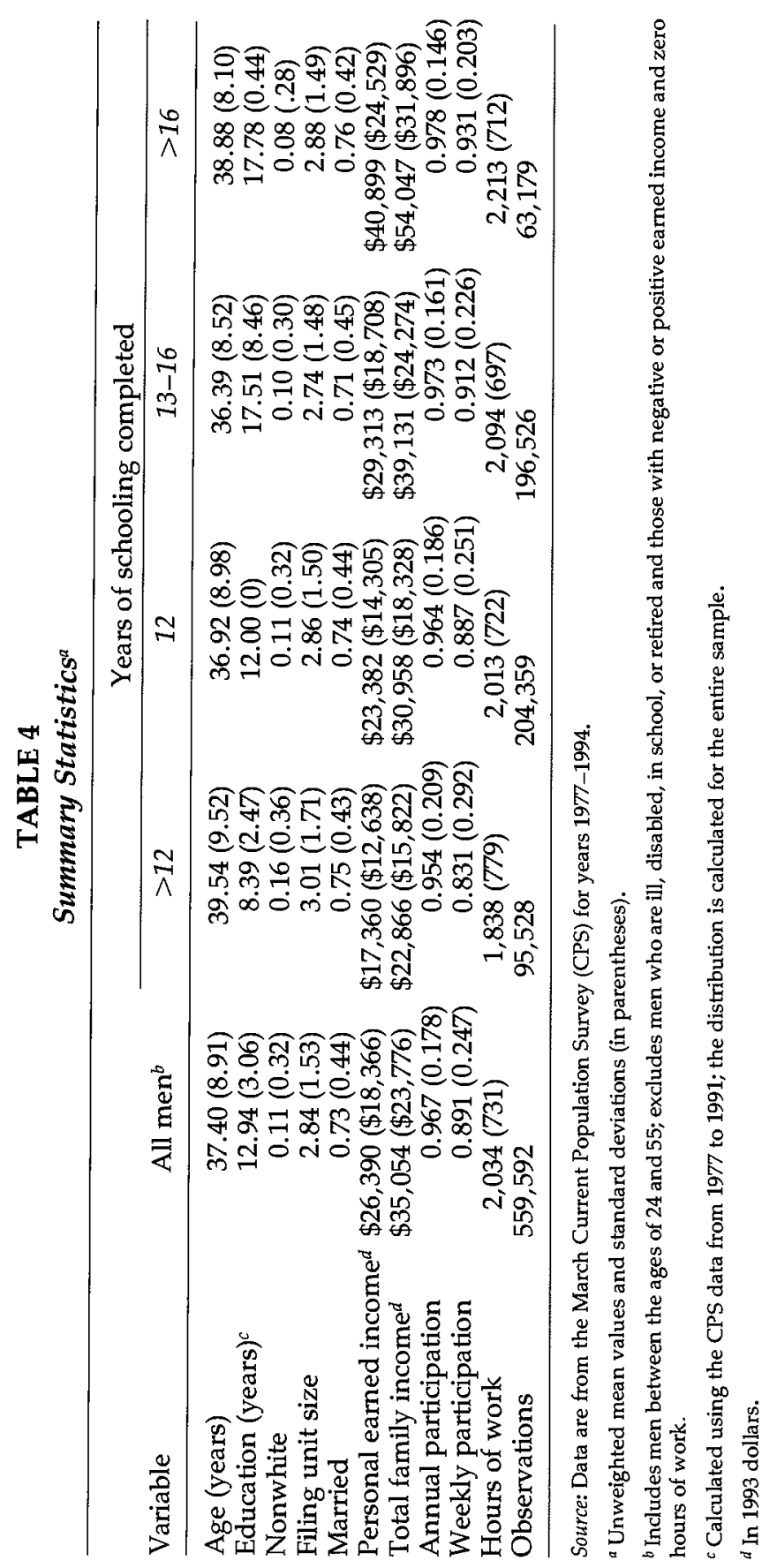


only the eighth grade, is 2 years older than the average man, and is less attached to the labor force. In contrast, the average man who has completed college continues his education for almost 2 years (the CPS top codes education at 18 years, so that many of these men might attain more than 2 years of graduate education) and is slightly more attached to the labor force.

\subsection{Basic Regression Results}

In this section, I present the basic labor supply regression and results. I use three measures of labor supply. The first measure is annual participation, defined by whether the individual worked any hours during the year. The other two measures are intended to better capture attachment to the labor force: percent of weeks worked, defined as weeks worked divided by 52 (weekly participation) and annual hours worked.

The tax laws define three periods over which one can analyze labor supply behavior: 1976-1981 (before tax reform), 1982-1986 (the ERTA), and 1987-1993 (the TRA of 1986). Recall that the ERTA was phased in between 1981 and 1984, whereas the TRA was phased in between 1986 and 1988. If the labor supply response is sluggish, these differences suggest that we are less likely to observe the full response to the ERTA than to the TRA.

To motivate the form of the regressions estimated, consider the factors that may have affected the male labor supply pattern between 1976 and 1993. First, business cycle effects are quite important during this period, especially in the early 1980s. Second, average levels of school completion increased steadily over this period (Murphy and Welch, 1992). The change in the composition of men in the respective education groups over time might also help explain the observed pattern of labor supply. ${ }^{18}$ Finally, important changes in the population structure occurred during this time. The peak of the baby boom generation entered the labor market between 1973 and 1980. Change over time in the skill or tastes of successive cohorts conflates the response to taxes.

To address these concerns, I estimate the following equation:

$$
l_{i t}=f\left(\alpha_{0}+\alpha_{1} Q_{i t}+\beta \mathrm{ERTA}_{i t}+\gamma \mathrm{TRA}_{i t}\right),
$$

where ERTA is a dummy variable equal to 1 for tax years between 1982 and 1986; TRA is a dummy variable equal to 1 for tax years after 1986 (the excluded period is pre-tax reform); and $f$ is the normal density function in the analysis of participation. The set of controls includes unearned

18 Appendix Tables 1 and 2 present the average characteristics of the sample, classified by education. 
TABLE 5

Coefficients from Labor Supply Regressions: Period Dummy Variables

ERTA

TRA

(1982-1986)

(1987-1993)

Panel A: Annual Participation (Probit)

\begin{tabular}{llr}
\hline All men & $-0.156(0.11)$ & $-0.014(0.02)$ \\
Education & $-0.289(0.24)$ & $-0.205(0.04)$ \\
Less than high school & $-0.135(0.18)$ & $0.019(0.03)$ \\
High school & $-0.113(0.20)$ & $0.066(0.03)$ \\
College & $-0.086(0.37)$ & $0.057(0.06)$ \\
Beyond college &
\end{tabular}

Panel B: Weekly Participation (OLS)

\begin{tabular}{lcc}
\hline All men & $-0.218(0.001)$ & $-0.003(0.002)$ \\
$\begin{array}{l}\text { Education } \\
\text { Less than high school }\end{array}$ & $-0.425(0.003)$ & $-0.015(0.004)$ \\
High school & $-0.255(0.002)$ & $0.000(0.003)$ \\
College & $-0.108(0.002)$ & $0.003(0.003)$ \\
Beyond college & $-0.005(0.003)$ & $0.002(0.004)$ \\
\hline \multicolumn{2}{c}{ Panel C: Total Hours Worked (OLS) } \\
\hline All men & $-67.66(3.19)$ & $1.13(4.81)$ \\
Education & & \\
Less than high school & $-126.02(7.91)$ & $-62.06(12.01)$ \\
High school & $-74.89(5.27)$ & $12.42(7.92)$ \\
College & $-40.78(5.38)$ & $19.34(8.11)$ \\
Beyond college & $-22.50(9.16)$ & $24.59(13.83)$ \\
\hline
\end{tabular}

Note: Data are from the March Current Population Survey from 1976 to 1993. Regressions include education and education squared for the sample of all men only; age and age squared, unearned income, family size, a dummy variable for marital status ( $=1$ if married), a dummy variable for race $(=1$ if nonwhite), business cycle controls (contemporaneous and lagged gross domestic product growth rate), and cohort dummy variables. Data are presented as mean value (standard error).

income, age and its square, education and its square, marital status, children, race ( $=1$ if nonwhite), and current and lagged gross domestic product (GDP) growth rates. 19,20

Panels A-C of Table 5 present the coefficients from regression equation

19 I define eight dummy cohorts: men born during the periods 1921-1930, 1930-1940, 1940$1945,1945-1950,1950-1955,1955-1960,1960-1965,1965-1970$. The excluded dummy is 1965-1970.

${ }^{20}$ The regressions do not include the hourly wage for two reasons: it is (1) undefined for nonworkers, and (2) measured with error that is negatively correlated with total hours for workers. Because these are reduced-form regressions and the wage is excluded, no meaningful interpretation is attached to the demographic controls in the regressions. 
(3) for the entire sample and for samples separated by educational attainment. Panel A presents probit coefficients, and panels $B$ and $C$ present ordinary least squares (OLS) coefficients. The results show a uniform decline in all labor supply measures during the ERTA period, with the most severe decline for men without a high-school degree. The coefficients for the TRA variable show that labor supply remained at levels below the pre-tax reform period for this group (the excluded years in these regressions are 1976-1981). The TRA coefficients for all other groups show an increase in labor supply relative to the pre-tax reform period. Since the change in labor supply relative to the ERTA period determines the size of the TRA effect, these coefficients need to be transformed.

Table 6 reinterprets the results of Table 5. The first column reports the average labor supply for each group in the excluded period, and the second and third columns present the average change in participation after the ERTA and TRA (relative to the previous period). All three panels show marginal effects. Panel A presents the marginal effects calculated from probits of annual participation, and panels $B$ and $C$ present the coefficients from OLS regressions of weekly participation and total annual hours.

After controlling for individual characteristics and business cycle and cohort effects, the results for all men show a labor supply decline of 1.086 percentage points in annual participation (67.66 total hours) in the ERTA period and a rise of 1.178 percentage points (68.79 total hours) in the TRA period for all men.

Different rows in each panel present estimates from regressions that use different samples. Men with less than 12 years of education show a consistently larger decline in all measures after the ERTA than all other groups. All measures of labor supplied by men with less than 12 years of schooling show a rise after the TRA that is smaller than that decline after ERTA, so that by the late 1980s and early 1990s, labor supplied by less educated men is still lower than it had been in the late 1970s. Slightly surprising in Table 6 are the small absolute changes in labor supplied by men with more than 16 years of schooling. This group, however, had the strongest attachment to the labor force to begin with so that smaller absolute responses may not be so surprising. The percent reduction in annual nonparticipation by highly educated men is similar to that of male college and high-school graduates (26 versus 28.7 and 24 percent, respectively).

Once relevant factors are controlled for, average changes in labor supply are only weakly correlated with tax changes. Because this approach averages data over many years, however, year effects may bias the results. Year effects derive from shifts in the aggregate labor supply function and from changes over time in wages. To address this issue and to 


\section{TABLE 6}

\section{Labor Market Participation of Men: Period Dummy Regression Variables}

\begin{tabular}{|c|c|c|c|}
\hline & \multirow[b]{2}{*}{$\begin{array}{c}\text { Pre-tax reform level } \\
\quad(1976-1981)\end{array}$} & \multicolumn{2}{|c|}{$\begin{array}{l}\text { Average change in labor } \\
\text { supply relative to } \\
\text { previous period }\end{array}$} \\
\hline & & $\begin{array}{c}\text { ERTA } \\
(1982-1986)\end{array}$ & $\begin{array}{c}\text { TRA } \\
(1987-1993)\end{array}$ \\
\hline \multicolumn{4}{|c|}{ Panel A: Annual Participation } \\
\hline All men & 96.7 & -1.086 & 1.178 \\
\hline \multicolumn{4}{|l|}{ Education } \\
\hline Less than high school & 97.1 & -2.591 & 0.857 \\
\hline High school & 96.3 & -0.995 & 1.128 \\
\hline College & 96.9 & -0.666 & 1.032 \\
\hline Beyond college & 97.1 & -0.420 & 0.688 \\
\hline \multicolumn{4}{|c|}{ Panel B: Weekly Participation } \\
\hline All men & 89.3 & -2.037 & 1.976 \\
\hline \multicolumn{4}{|l|}{ Education } \\
\hline Less than high school & 86.0 & -4.250 & 2.740 \\
\hline High school & 89.2 & -2.545 & 2.549 \\
\hline College & 90.7 & -1.083 & 1.357 \\
\hline Beyond College & 92.0 & -0.484 & 0.710 \\
\hline \multicolumn{4}{|c|}{ Panel C: Total Hours Worked } \\
\hline All men & $2,042.6$ & -67.66 & 68.79 \\
\hline \multicolumn{4}{|l|}{ Education } \\
\hline Less than high school & $1,929.7$ & -126.02 & 63.96 \\
\hline High school & $2,038.0$ & -74.89 & 87.30 \\
\hline College & $2,079.5$ & -40.78 & 60.12 \\
\hline Beyond college & $2,168.3$ & -22.50 & 47.09 \\
\hline
\end{tabular}

Note: Data are from the March Current Population Survey, 1976-1993; participation figures are based on 100 percentage points.

exploit the timing of the responses, I next examine more carefully the trends in labor supply over time.

\subsection{Labor Supply Trends}

To separate the effects of the tax reforms from those of differential wage growth and aggregate labor supply trends, assume that growing wage inequalities affect the trend from 1976 to 1993 and that the ERTA and TRA affect the trend at 1982 and 1987, respectively. This approach is 
similar to that used by Bosworth and Burtless (1992) using aggregate data from 1968 to 1990 . They allowed one trend starting in 1982. With 6 years of data after 1987, a separate trend for TRA can be estimated.

The estimated regression takes the following form:

$$
l_{i t}=f\left(\alpha_{0}+\alpha_{1} Q_{i t}+\beta \text { Time }_{t}+\gamma \text { Time82 }_{t}+\delta \text { Time87 }_{t}\right.
$$

where Time is a trend starting in 1976; Time82 is a trend starting in 1982; Time 87 is a trend starting in $1987 . \beta$ reflects the patterns in labor supply due to aggregate trends, such as wage growth; and $\gamma$ and $\delta$ reflect the effects of the tax reforms.

Table 7 presents the results. Again, all panels present marginal effects, and different rows present results for different samples, separated by educational attainment. The estimates for all men show a decline in all three measures of participation starting in 1977 and increases starting in 1982 and 1987. Labor force participation by prime-age men increased by 0.113 percentage points per year after the ERTA and by 0.210 percentage points per year after the TRA. Total hours worked fell at a rate of 13.43 per year starting in 1977 and rose by almost 6 hours per year after the ERTA and by an additional 5.7 hours after the TRA. ${ }^{21}$

The rate of decline throughout the period and the rate of increase after the ERTA are generally largest for less educated groups (second and third columns). Annual participation by men with less than 12 years of schooling fell at a rate of 0.351 percentage points per year starting in 1977 and rose by 0.141 percentage points a year after the ERTA and by 0.260 percentage points after the TRA. Total hours worked increased by 6.35 hours per year after the ERTA and by 15.42 hours per year after the TRA. The increase after the ERTA is difficult to interpret because marginal and average rates generally rose for lower income individuals.

A conservative interpretation of these results is that the ERTA trend partially captures the recovery from the recession of the early 1980s and other factors unaccounted for in the regressions but not the tax changes. Even under that interpretation, the evidence suggests a response to the TRA. The labor supply continues to increase after 1986 and in a pattern that is consistent with the marginal tax changes in the TRA. The largest annual responses are by men with less than 12 and more than 16 years of schooling. Between 1987 and 1990, the annual participation rate of the least educated rose by 1.04 percentage points, and total hours worked

${ }^{21}$ The hours-of-work results are most comparable to Bosworth and Burtless (1992). By 1989 , men worked a total of 130 hours per year more than in 1981. This estimate translates into a 6.5 percent increase in total hours worked compared with 6 percent in the Bosworth and Burtless analysis. 
TABLE 7

Labor Market Participation of Men: Time Trend Regressions

\begin{tabular}{ccc}
\multicolumn{3}{c}{ Annual change in labor supply } \\
\hline Time & Time82 & Time87 \\
$(1976-1981)$ & $(1982-1986)$ & $(1987-1993)$
\end{tabular}

Panel A: Annual Participation

\begin{tabular}{llll}
\hline All men & $-0.141(0.00)$ & $0.113(0.00)$ & $0.210(0.03)$ \\
Education & & & \\
$\quad$ Less than high school & $-0.351(0.07)$ & $0.141(0.11)$ & $0.260(0.09)$ \\
High school & $-0.142(0.04)$ & $0.259(0.07)$ & $0.125(0.06)$ \\
College & $-0.047(0.04)$ & $0.068(0.06)$ & $0.252(0.05)$ \\
Beyond college & $-0.019(0.06)$ & $0.013(0.09)$ & $0.295(0.08)$ \\
\hline
\end{tabular}

Panel B: Weekly Participation

\begin{tabular}{lccc}
\hline All men & $-0.272(0.04)$ & $0.269(0.06)$ & $0.208(0.05)$ \\
Education & & & \\
$\quad$ Less than high school & $-0.466(0.10)$ & $0.168(0.16)$ & $0.546(0.14)$ \\
High school & $-0.431(0.04)$ & $0.535(0.10)$ & $0.128(0.86)$ \\
College & $-0.013(0.06)$ & $0.090(0.09)$ & $0.112(0.07)$ \\
Beyond college & $0.153(0.10)$ & $-0.249(0.15)$ & $0.290(0.12)$ \\
\hline
\end{tabular}

Panel C: Total Hours Worked

\begin{tabular}{lccc}
\hline All men & $-13.43(1.11)$ & $15.83(1.71)$ & $5.71(1.37)$ \\
Education & & & \\
$\quad$ Less than high school & $-17.41(2.60)$ & $6.35(4.24)$ & $15.42(3.68)$ \\
High school & $-17.20(1.84)$ & $22.18(2.85)$ & $4.13(2.29)$ \\
College & $-7.77(1.90)$ & $14.36(2.87)$ & $2.15(2.21)$ \\
Beyond college & $-3.38(3.28)$ & $7.26(5.03)$ & $7.76(4.02)$ \\
\hline
\end{tabular}

Note: Data are from the March Current Population Survey, 1976-1993. Regressions include education and education squared for the sample of all men only; age and age squared, unearned income, family size, a dummy variable for marital status ( $=1$ if married), a dummy variable for race (=1 if nonwhite), business cycle controls (contemporaneous and lagged GDP growth rate), and cohort dummy variables. Participation figures are based on 100 percentage points. Data are presented as mean value (standard error).

Time, pre-tax reform; Time82, Economic Recovery Tax Act of 1981; Time87, Tax Reform Act of 1986.

increased by 61.6 hours per year. For the most educated group, annual participation rose by 1.2 percentage points and total hours worked rose by 31 hours per year.

\subsection{Alternative Specifications}

The previous estimates are preferable to the initial estimates because they use the timing of the tax laws to identify the response. However, they are restrictive in that they impose linear trends. An even more 


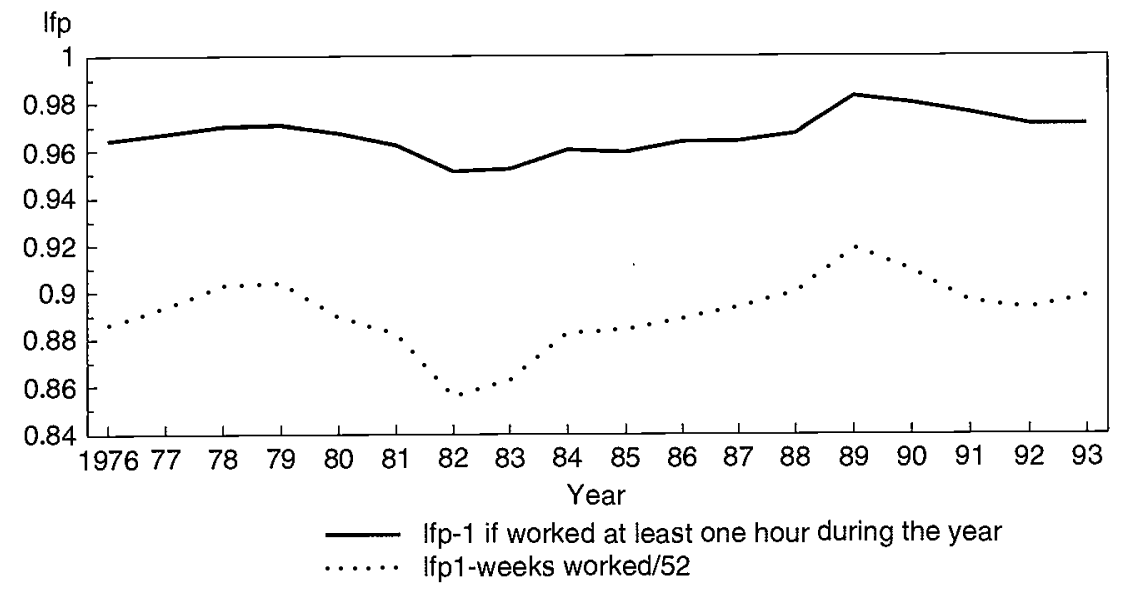

FIGURE 1. Labor force participation rate, 1976-1993.

flexible method of analyzing the response is to plot labor supply trends over time. Figure 1 presents the average (annual and weekly) participation rate of men between 1976 and 1993. The two measures have different mean values but show similar patterns. The effect of the recession in the early 1980s is evident from the data; the participation rate falls from 1979 to 1982, after which the recovery starts. Figure 1 suggests that it is difficult to disentangle the effect of the ERTA from the effect of the recession because of the timing of the tax law; however, the effect of the TRA is clearer.

To purge the trend from the effects of changes in observable characteristics and cohort effects, I estimate regressions with 17-year dummy variables and the same observable characteristics included in previous regressions. Separate regressions are estimated for each education group. The marginal effects calculated from the coefficients for the year dummy variables are plotted in Figures 2 and 3. Several observations are clear. First, the significant heterogeneity across groups in the labor supply trend is apparent. The least educated group showed no increase in labor supply after 1987; in fact, the labor supply declined. Predicted labor market participation by men with less than 12 years of education never fully recovered from the recession of the early 1980s. Between 1978 and 1982, the GDP growth rate fell by 7 percentage points, from 4.5 to -2.5 . Labor force participation by men with less than 12 years of education fell by more than 4 percentage points. 


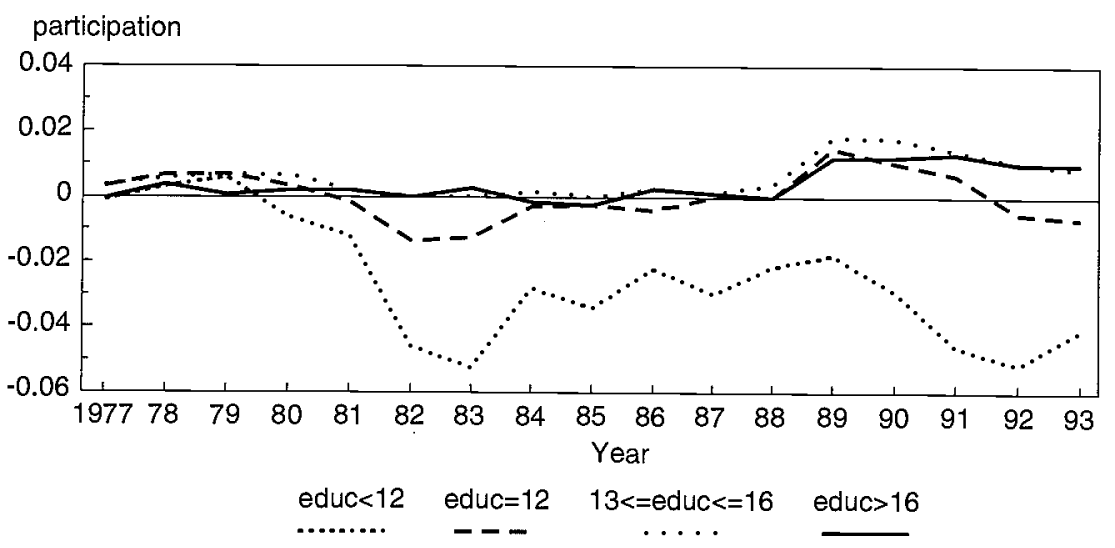

FIGURE 2. Marginal effects: probability of participation, 1977-1993.

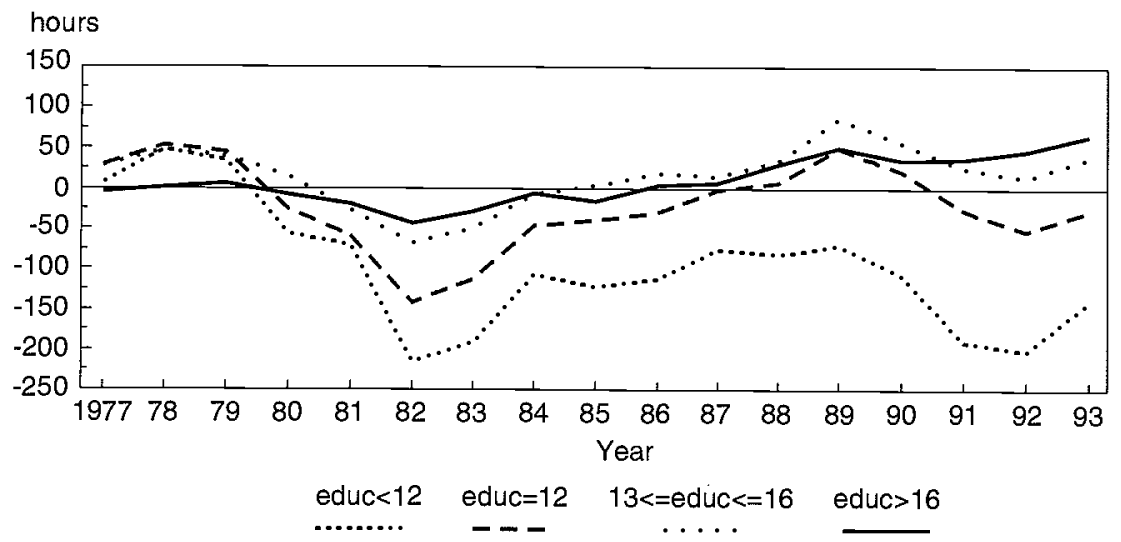

FIGURE 3. Coefficients of year dummy variables: annual hours, 19771993.

The participation rate of men with more than 12 years of education shows some responsiveness to the TRA: it jumps between 1 and 2 percentage points in 1987. Although we observe similar jumps in participation rates by men with 12 years of schooling, their participation immediately declines starting in 1988. No such jumps in hours worked are observed for the most educated men, which is the only group that does not show any decline in total hours worked after 1989 (Figure 3). Over- 
all, Figures 1-3 suggest that evidence of a male labor supply response to the tax reforms is quite weak.

\section{DISCUSSION AND CONCLUSION}

The tax reforms of the 1980s provided economists with a remarkable opportunity to evaluate individual behavioral responses to tax reforms. This paper has reviewed the evidence from the literature and presented new evidence on individual behavioral responses to tax reforms.

It is useful to conclude by considering what we have not learned from the evidence summarized and presented in this paper. Studies that directly analyzed the labor supply present evidence that the female labor supply is responsive to taxes. The question that arises is, What parameters do these studies estimate? ${ }^{22}$ The "difference-in-difference" approach estimates the net response to the tax reforms, which amounts to the uncompensated response. Generally, then, we have not learned from this evidence the preference parameters needed to evaluate tax reforms. There are exceptions, however. The results in Eissa (1995a) may be interpreted as compensated labor supply elasticities, since the TRA had a small income effect. Still, none of the work has isolated the income elasticity of hours worked or participation. ${ }^{23}$ Separating the income and substitution effects requires more structural modeling of labor supply behavior and stronger assumptions about functional form (see Blundell, Duncan, and Meghir, 1995). ${ }^{24}$

22 In principle, the change in labor supply after the tax reforms includes intertemporal substitution and income and substitution effects. Individuals may intertemporally substitute labor supply if they foresee the tax change, or if they believe it to be temporary. Both the ERTA and TRA were phased in over time, and so we should expect that some intertemporal substitution in labor supply occurred. However, several reasons suggest that the intertemporal substitution effects will be small. Using data on hours worked, empirical labor supply research shows little intertemporal substitution (see Heckman, 1993). Also, Hausman and Poterba (1987) argue that the after-tax rate of return is not substantially affected for many households. In a life-cycle model of labor supply, both the path of aftertax wages and after-tax returns matter for labor supply decisions. A stronger reason to suspect that we estimate a long-run response is that the studies cover periods that completely bracket the tax changes.

${ }^{23}$ The income effect is necessary for applied welfare analysis if taxpayers are making a discrete choice, such as whether or not to participate in the labor force (Small and Rosen, 1981).

${ }^{24}$ Blundell, Duncan, and Meghir (1995) estimate a structural model of labor supply that identifies the income and substitution effects from the tax reforms that took place in England over the 1980s. The reforms raised and lowered rates during the 1980s. Blundell, Duncan, and Meghir use these changes, along with the change in returns to education that varied by cohorts, to identify the income and wage effects of the tax reform. Applying their 
There is an important trade-off here. Although structural models of labor supply yield preference parameters that can be used for welfare analysis of tax reform, they have been widely criticized for the restrictive assumptions imposed (MaCurdy, Green, and Paarsch, 1990) and for their sensitivity to the preference and model specifications used (Heckman, 1982; Triest, 1990). By focusing on affected groups and using arguably more exogenous variation in marginal rates, the natural experiment approach minimizes the potential for functional form assumptions to bias the results. ${ }^{25}$ Difference-in-difference approaches rely on more transparent assumptions to identify the tax effect. The advantage of that strategy is that the direction and size of any biases become transparent. The disadvantage is that it generally does not yield the preference parameters.

Building on the evidence that shows an increase in taxable income by higher income individuals after the tax reforms, the current paper also analyzed whether those responses were due to an increase in male labor market participation. Although high-income married women have been shown to be quite sensitive to the changes in marginal rates, their increased labor supply does not explain the large increase in income observed in tax return data. Women married to high-income men do not earn enough to explain the surge in income.

Microdata from 1976 to 1993 show only weak evidence of a small increased male labor supply response after the TRA of 1986. For men with 16 years of schooling, the trend regressions show an increase in total hours of work of about 50 hours per year, or 2 percent. This response is much smaller than what the studies on the income response suggest (Feenberg and Poterba, 1993; Auten and Carroll, 1995; Feldstein, 1995; Slemrod, 1995) and suggest that the income response observed in the tax return data is due more to factors other than labor market participation, such as shifting of income and compensation decisions. Finally, one cannot conclude from this evidence that the labor supply of men more broadly defined to include work effort, occupational choice, and human capital accumulation, showed little response to the tax reforms.

approach to the United States would be very involved because the U.S. tax code is far more complicated than the British tax code.

${ }^{25}$ For example, one does not need to use after-tax wages in the regression, which are measured with error in survey data (Mroz, 1987); neither does one need to impute wages for individuals out of the labor force. 


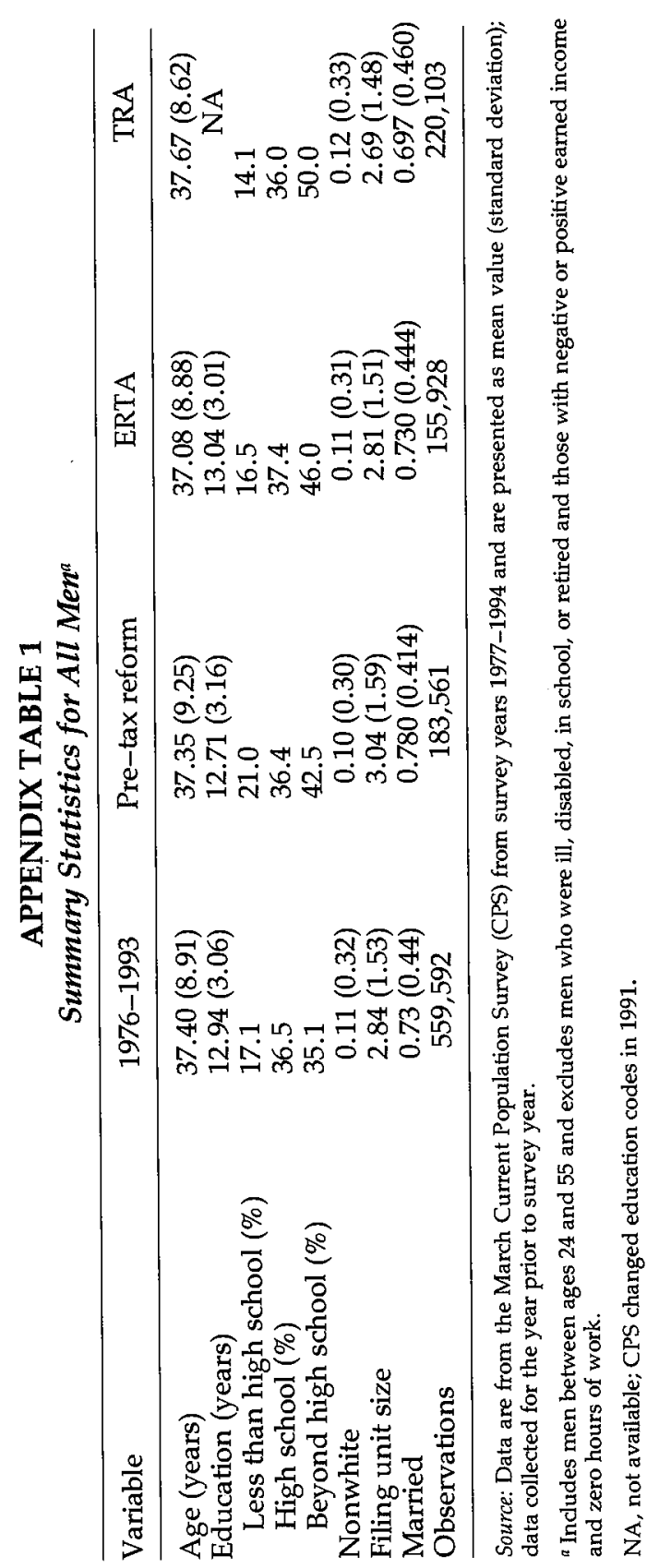




\section{APPENDIX TABLE 2}

Summary Statistics for All Men by Education ${ }^{a}$

\begin{tabular}{lcccc}
\hline Variable & Pre-tax & ERTA & TRA \\
\hline Less than high school & $1976-1993$ & reform & & \\
$\quad$ Age (years) & $39.54(9.52)$ & $41.69(9.47)$ & $39.29(9.59)$ & $38.30(9.36)$ \\
Education (years) & $8.39(2.47)$ & $8.34(2.43)$ & $8.45(2.45)$ & NA \\
Nonwhite (\%) & $0.16(0.36)$ & & & \\
Filing unit size (no.) & $3.01(1.71)$ & $3.24(1.78)$ & $2.96(1.66)$ & $2.77(1.61)$ \\
Married (no.) & $0.75(0.43)$ & $0.803(0.398)$ & $0.746(0.435)$ & $0.683(0.465)$ \\
Observations (no.) & 95,528 & 38,779 & 25,793 & 30,956 \\
Beyond college & & & & \\
Age (years) & $38.88(8.10)$ & $37.5(8.24)$ & $38.7(7.99)$ & $40.2(7.85)$ \\
Education (years) & $17.78(0.44)$ & $17.7(0.451)$ & $17.7(0.438)$ & NA \\
Nonwhite (\%) & $0.08(.28)$ & & & $2.85(1.47)$ \\
Filing unit size (no.) & $2.89(1.49)$ & $2.99(1.54)$ & $2.85(1.46)$ \\
Married (no.) & $0.76(0.42)$ & $0.777(0.417)$ & $0.756(0.429)$ & $0.760(0.427)$ \\
Observations (no.) & 63,179 & 20,421 & 18,678 & 24,080 \\
\hline
\end{tabular}

Source: Data are from the March Current Population Survey (CPS) from survey years 1977-1994 and are presented as mean value (standard deviation).

${ }^{a}$ Includes men between ages 24 and 55 and excludes men who were ill, disabled, in school, or retired and those with negative or positive earned income or zero hours of work.

NA, not available; CPS changed education codes in 1991.

\section{REFERENCES}

Auten, Gerald, and Robert Carroll (1995). "Taxpayer Behavior and the 1986 Tax Reform Act." Treasury Department, Office of Tax Analysis. Mimeograph.

Blundell, Richard, Alan Duncan, and Costas Meghir (1995). "Estimating Labor Supply Responses Using Tax Reforms." The Institute for Fiscal Studies. Mimeograph.

Bosworth, Barry, and Gary Burtless (1992). "Effects of Tax Reform on Labor Supply, Investment, and Saving." Journal of Economic Perspectives 6(no. 1):3-26.

Deloitte and Touche (1993). "Shifting the Burden; The 1993 Tax Changes." Deloitte, Touche, Tohmatsu: International.

Eissa, Nada (1995a). "Taxation and Labor Supply of Married Women: The Tax Reform Act of 1986 as a Natural Experiment." NBER Working Paper no. 5023.

- (1995b). "Labor Supply Response to the Economic Recovery Tax Act of 1981." Paper presented at NBER Conference on Tax Policy Analysis, Islamoradaadora, FL, January.

_ Income Tax Credit." NBER Working Paper no. 5158. Forthcoming in Quarterly Journal of Economics.

Feenberg, Daniel, and James Poterba (1993). "Income Inequality and the Incomes of Very High Income Taxpayers." In Tax Policy and the Economy, vol. 7, pp. 145-177, James Poterba (ed.). Cambridge, MA: MIT Press. 
Feldstein, Martin (1995). "The Effect of Marginal Tax Rates on Taxable Income: A Panel Study of the 1986 Tax Reform Act." Journal of Political Economy. Vol. 103, no. 3, pp. 551-572.

, and Andrew Samwick (1992). "Social Security Rules and Marginal Tax Rates." National Tax Journal 45 (no. 1):1-22.

Hausman, Jerry (1981). "Labor Supply." In How Taxes Affect Economic Behavior, Henry Aaron and Joseph Pechman (eds.). Washington, DC: The Brookings Institution.

Institution. (1985). "Taxes and Labor Supply." In Handbook of Public Economics, Vol. I, Alan Auerbach and Martin Feldstein (eds.). Amsterdam: Elsevier.

- and James Poterba (1987). "Household Behavior and the Tax Reform Act of 1986." Journal of Economic Perspectives 1(no. 1):101-120.

Heckman, James. (1993). "What Has Been Learned About Labor Supply in the Past Twenty Years?" American Economic Review 83(no. 2):116-121.

—, and Mark Killingsworth. "Female Labor Supply." In Handbook of Labor Economics. Vol. I. Orley Ashenfelter and Richard Layard (eds.). Amsterdam: Elsevier.

Juhn, Chin-hui (1992). "Decline of Male Labor Market Participation: The Role of Declining Market Opportunities." Quarterly Journal of Economics Vol. 107, no. 1, pp. 79-121.

Katz, Lawrence, and Kevin Murphy (1992). "Changes in Relative Wages, 19631987: Supply and Demand Factors." Quarterly Journal of Economics 107(no. 1):35-78.

Lindsey, Lawrence. (1987). "Individual Taxpayer Response to Tax Cuts, 19821984: With Implications for the Revenue Maximizing Tax Rate." Journal of Public Economics 33:173-206.

(1988). "Did ERTA Raise the Share of Taxes Paid by Upper-Income Taxpayers? Will TRA86 Be a Repeat?" In Tax Policy and the Economy, Vol. 2, Lawrence Summer (ed.). Cambridge: MIT Press, 131-160.

MaCurdy, Thomas, David Green, and Harry Paarsch (1990). "Assessing Empirical Approaches for Analyzing Taxes and Labor Supply." The Journal of Human Resources 25(no. 3):415-490.

Mroz, Thomas (1987). "Sensitivity of an Empirical Model of Married Women's Hours of Work to Economic and Statistical Assumptions." Econometrica 55(no. 4):765-799.

Murphy, Kevin, and Finis Welch (1992). "The Structure of Wages." Quarterly Journal of Economics 107(no. 1):285-326.

Navratil, John (1994). "Evidence of Individual Taxpayer Behavior from Panel Tax Return Data." Harvard University. Mimeograph.

Pechman, Joseph (1987). Federal Tax Policy. Washington, DC: The Brookings Institution.

Pencavel, John (1986). "Labor Supply of Men: A Survey." In Handbook of Labor Economics, Vol. I, Orley Ashenfelter and Richard Layard (eds.). Amsterdam: Elsevier.

Slemrod, Joel (1995). "High-Income Families and the Tax Changes of the 1980's: The Anatomy of Behavioral Response." NBER Working Paper no. 5218.

Small, Kenneth, and Harvey Rosen (1981). "Applied Welfare Analysis With Discrete Choice Models." Econometrica, Vol. 49, no. 1, pp. 105-130. 
Triest, Ronald (1990). "The Effect of Income Taxation on Labor Supply in the United States." The Journal of Human Resources 25(no. 3):491-516. . 1992. "The Effect of Income Taxation on Labor Supply When Deductions Are Endogenous." The Review of Economics and Statistics 25(no. 3):91-99. 